\title{
The Parametric Oscillations of Heterogeneous Round Cylindrical Shell of Variable Density on Different Boundary Conditions
}

\begin{abstract}
A. A. Mochalin
Saratov State Technical University named after Yu.A. Gagarin, 77, Politeknicheskaya st., 410054, Saratov, Russia, a.mochalin@inbox.ru

We consider an isotropic cylindrical shell of varying thickness and density along the generatrix. Let the shell be under pressure, which is symmetric and also varying along the generatrix. We follow the polupostamenty theory by V. Z. Vlasov and consider the problem of the dynamical stability of the shell. We obtain the exact solution corresponding to the certain relation between thickness, pressure and density. Such kind of shells of extent medium is important in mechanical and aerospace engineering for optimal mass obtaining. In the paper we obtain minimum values of the excitation coefficients for five boundary value problems, which are of great importance in engineering. We give the accuracy estimation of the WKB method for these problems. Numerical results are summarized in the table.
\end{abstract}

Key words: cylindrical shell, theory of shells, parametric oscillations of shells, radial loading, shell thickness, theory of elasticity, coefficients of excitation, dynamic stability.

\section{References}

1. Belov S. V. Poristyie metally v mashinostroenii [Porous metals applications in mechanical engineering]. Moscow, Mashinostroenie, 1981, 248 p. (in Russian).

2. Boldyrev A. B. Primenenie modelei tverdogo deformiruiemogo tela peremennoi plotnosti $\mathrm{V}$ zadachah optimizacii i progozirovaniya massy aviacionnyh construccii [Application of models of solid deformable body of variable density in problems of optimization and prediction of the mass of the airframe]. Collection of scientific papers Science and technology. The results of the dissertation research. Ser. Selected works of the Russian school, Moscow, Russian Academy of Sciences, 2009, vol. 1, pp. 177-200 (in Russian).

3. Vlasov V. Z. Obshchaya teoriia obolochek [General theory of shells]. Moscow, GITTL, 1949, $784 \mathrm{p}$. (in Russian).

4. Mochalin A. A. Ustoichivost neodnorodnoi cylindri-

cheskoi obolochki ot neravnomernoi radialnoi nagruzki [Stability of non-homogeneous cylindrical about-shell from the uneven radial Noi load]. Problems of machine engineering companies and reliability, Moscow, 2014, no. 1, pp. 12-17 (in Russian)

5. Salnikov G. M. Dinamicheskaya ustoichivost' cylindricheskikh i konicheskikh obolochek krugovogo i nekrugovogo secheniya pri razlichnykh granichnykh usloviyakh [Dynamic stability of cylindrical and conical shells of circular and non-circular cross-section with various boundary conditions]. The Collection Research on the theory of PLA-plates and shells, Kazan, 1967, no. 5, pp. 469-479 (in Russian).

6. Bolotin V. V. Dynamicheskaya ustoichivost' uprugikh system [Dynamic us-persistence of elastic systems]. Moscow, GITTL, 1956, 600 p. (in Russian)

\section{NEAR-RESONANT REGIMES OF A STEADY-STATE MOVING LOAD ON A TRANSVERSELY ISOTROPIC ELASTIC HALF-PLANE}

\section{A. Prikazchikov}

School of Computing and Mathematics, Keele University, Keele, Staffordshire, ST5 5BG, UK, d.prikazchikov@keele.ac.uk

\begin{abstract}
A moving load problem on a transversely isotropic elastic half-plane is considered under steady-state assumption. The approach relies on the hyperbolic-elliptic asymptotic model for surface wave, allowing drastic simplifications. In particular, the formulation is reduced to a Dirichlet problem for a scaled Laplace equation having a straightforward solution in terms of elementary functions. The obtained approximate solutions are valid for loads travelling at speeds close to surface wave speed.
\end{abstract}

Key words: moving load, transversely isotropic, near-resonant. 


\section{INTRODUCTION}

The practical importance of moving load problems is increasing, especially in view of the rapid development of high-speed railway operation, see e.g. [1,2]. It is well-known, that surface wave speed is critical for a moving load on an elastic solid, both within theoretical and experimental setup $[3,4]$. Therefore, analysis of the near-resonant regimes is an issue of particular significance.

This paper is concerned with analytical treatment of the near-resonant regimes of a point force moving steadily at a constant speed along the surface of a transversely isotropic elastic half-plane. Similarly to isotropic media, the exact solution of the problem may be expressed in integral form, see e. g. [5], which is not straightforward for further analysis. This stimulates various approximate approaches, for example that for soil dynamics, preserving vertical displacement only [6].

The approach of this paper relies on a recently proposed methodology related to approximate formulation for surface wave field, see [7], and [8] for more details. This asymptotic formulation involves a hyperbolic equation on the surface describing the wave propagation and an elliptic equation over the interior governing the decay away from the surface, being first derived in [9] by means of the symbolic Lourier method. Later the same result was obtained in [10] through a slow-time perturbation of the free eigensolution in terms of a single plane harmonic function [11]. The approach was also extended to 3D case and has been successfully applied to moving load problems $[12,13]$. The methodology relies on the general assumption of dominance of surface wave field compared to that arising from the bulk waves, which is physically justified for the case of near-resonant regimes of the moving load.

The model in [10] has also been generalized to a transversely isotropic media [14]. However, the representation of the surface wave field for a transversely isotropic media in terms of a single harmonic function has only become available after a recent contribution [15], which allowed drastic simplifications of the asymptotic formulation for the surface wave field.

Similarly to results for isotropic media, the considered moving load problem reduces to a Dirichlet problem for a scaled Laplace equation, with the boundary value provided by a $1 \mathrm{D}$ wave equation, thus enabling an elegant solution in terms of elementary functions. The resonant nature of the surface wave is clearly observed from the obtained solution. The results are expected to provide reasonable approximation in the near-surface vicinity for a range of speeds of the moving load close to that of surface wave speed.

\section{STATEMENT OF THE PROBLEM}

Consider a transversely isotropic half-plane $-\infty<x_{1}<\infty, 0 \leq x_{3}<\infty$ subjected to action of a point concentrated force moving steadily at a constant speed $c$ along the surface $x_{3}=0$ (Figure).

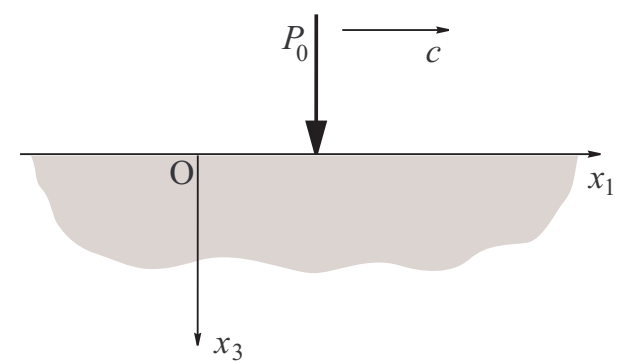

The load moving along the surface of a half-plane

The $2 \mathrm{D}$ equations of motion of linear elasticity are written in standard form

$$
\sigma_{11,1}+\sigma_{13,3}=\rho u_{1, t t}, \quad \sigma_{31,1}+\sigma_{33,3}=\rho u_{3, t t},
$$

where $\sigma_{i j}$ and $u_{i} \quad(i, j=1,3)$ are the stress tensor and displacement field components, respectively, $\rho$ is volume density, and a comma indicates differentiation along the associated spatial or time variable.

The constitutive relations of a transversely isotropic solid are adopted in the form

$$
\sigma_{11}=c_{11} u_{1,1}+c_{13} u_{3,3}, \quad \sigma_{13}=\sigma_{31}=c_{44}\left(u_{1,3}+u_{3,1}\right), \quad \sigma_{33,3}=c_{13} u_{1,1}+c_{33} u_{3,3},
$$


where $c_{i j}$ are stiffness tensor components expressed in Voigt contracted notation, see e.g. [16]. It is assumed that the coefficients $c_{i j}$ satisfy the conditions

$$
c_{11}>0, \quad c_{44}>0, \quad c_{11} c_{33}-c_{13}^{2}>0,
$$

ensuring positive definiteness of the strain-energy density, see [17].

The boundary conditions on the surface $x_{3}=0$ are specified in the form

$$
\sigma_{31}=0, \quad \sigma_{33}=P_{0} \delta\left(x_{1}-c t\right) .
$$

Using the constitutive relations (2) the problem may now be reformulated in terms of displacement components as

$$
\begin{aligned}
& c_{11} u_{1,11}+c_{44} u_{1,33}+\left(c_{13}+c_{44}\right) u_{3,13}=\rho u_{1, t t}, \\
& \left(c_{13}+c_{44}\right) u_{1,13}+c_{44} u_{3,11}+c_{33} u_{3,33}=\rho u_{3, t t},
\end{aligned}
$$

subject to the following boundary conditions at $x_{3}=0$

$$
u_{1,3}+u_{3,1}=0, \quad c_{13} u_{1,1}+c_{33} u_{3,3}=P_{0} \delta\left(x_{1}-c t\right) .
$$

\section{APPROXIMATE FORMULATION FOR THE SURFACE WAVE FIELD}

Using the results of [14], it is possible to present the approximate statement of the boundary value problem (5), (6), oriented towards extraction of the contribution of the surface wave to the overall dynamic response, thus neglecting the effect of the bulk waves. Clearly, a load moving at a speed close to that of surface wave speed, provides an example of surface wave field dominating those of the bulk waves, therefore the application of the asymptotic model [14] is justified.

According to the latter, the decay over the interior of a half-plane is governed by a system of elliptic equations

$$
\begin{aligned}
& \left(c_{11}-\rho c_{R}^{2}\right) u_{1,11}+c_{44} u_{1,33}+\beta u_{3,13}=0, \\
& \beta u_{1,13}+\left(c_{44}-\rho c_{R}^{2}\right) u_{3,11}+c_{33} u_{3,33}=0,
\end{aligned}
$$

where $\beta=c_{13}+c_{44}$. The boundary conditions on the surface $x_{3}=0$ include a hyperbolic equation for the horizontal displacement and a relation between the displacements, namely

$$
u_{1,3}+u_{3,1}=0, \quad u_{1, t t}-c_{R}^{2} u_{1,11}=A P_{0} \delta^{\prime}\left(x_{1}-c t\right),
$$

with $c_{R}$ denoting the surface wave speed, being the root of

$$
c_{33} c_{44} \rho^{2} c_{R}^{4}\left(c_{11}-\rho c_{R}^{2}\right)-\left(c_{44}-\rho c_{R}^{2}\right)\left[c_{33}\left(c_{11}-\rho c_{R}^{2}\right)-c_{13}^{2}\right]^{2}=0,
$$

see e. g. [18]. The coefficient $A$ in the hyperbolic equation (9) is a material constant given by

$$
A=\frac{1}{\rho B}\left(\beta \sqrt{\frac{\left(c_{11}-\rho c_{R}^{2}\right)\left(c_{44}-\rho c_{R}^{2}\right)}{c_{33} c_{44}}}+\rho c_{R}^{2}-c_{11}\right),
$$

where

$$
B=2 \rho c_{R}^{2}-c_{11}+\frac{c_{33}\left(\rho c_{R}^{2}-c_{11}\right)\left(c_{11}-4 \rho c_{R}^{2}+3 c_{44}\right)+c_{13}^{2}\left(c_{11}+c_{44}-2 \rho c_{R}^{2}\right)}{2 \sqrt{c_{33} c_{44}\left(c_{11}-\rho c_{R}^{2}\right)\left(c_{44}-\rho c_{R}^{2}\right)}}
$$

see [14].

It should be noted that the system (7), (8) is closely related to a recent representation of a free surface wave field in orthorhombic media [15] generalizing previous results of [11] and [19] for isotropic media.

Following [15], the eigensolution for the displacements may be written in terms of a single harmonic function as

$$
u_{1}\left(x_{1}, x_{3}, t\right)=\phi\left(x_{1}-c_{R} t, \lambda_{1} x_{3}\right)-\chi \phi\left(x_{1}-c_{R} t, \lambda_{2} x_{3}\right),
$$




$$
u_{3}\left(x_{1}, x_{3}, t\right)=\gamma_{1} \phi^{*}\left(x_{1}-c_{R} t, \lambda_{1} x_{3}\right)-\gamma_{2} \chi \phi^{*}\left(x_{1}-c_{R} t, \lambda_{2} x_{3}\right),
$$

where $\phi$ is an arbitrary plane harmonic function, a star superscript denotes the harmonic conjugate, $\lambda_{i}$ $(i=1,2)$ stand for the attenuation orders (ensuring decay as $\left.x_{3} \rightarrow \infty\right)$ determined from the characteristic equation

$$
c_{33} c_{44} \lambda^{4}-\left[c_{44}^{2}+c_{11} c_{33}-\beta^{2}-\left(c_{33}+c_{44}\right) \rho c_{R}^{2}\right] \lambda^{2}+\left(c_{11}-\rho c_{R}^{2}\right)\left(c_{44}-\rho c_{R}^{2}\right)=0,
$$

and

$$
\gamma_{i}=\frac{c_{44} \lambda_{i}^{2}-c_{11}+\rho c_{R}^{2}}{\beta \lambda_{i}}, \quad \chi=\frac{\gamma_{1}-\lambda_{1}}{\gamma_{2}-\lambda_{2}}, \quad(i=1,2)
$$

Using the relation (13), the boundary value problem (7)-(9) may be reduced to a scalar problem for a plane harmonic function $\phi$

$$
\phi_{, 33}+\lambda^{2} \phi_{, 11}=0
$$

subject to the boundary condition at $x_{3}=0$

$$
\phi_{, t t}-c_{R}^{2} \phi_{, 11}=\frac{A P_{0}}{1-\chi} \delta^{\prime}\left(x_{1}-c t\right) .
$$

The solution of the boundary value problem (17), (18) should then be substituted into representation (13), (14) to give the resulting displacement profile of surface wave field.

\section{ANALYSIS OF THE NEAR-RESONANT STEADY-STATE REGIME OF A MOVING LOAD}

Let us introduce a moving coordinate $\xi=x_{1}-c t$. The hyperbolic equation (18) then becomes

$$
\left(c^{2}-c_{R}^{2}\right) \phi_{, \xi \xi}(\xi, 0)=\frac{A P_{0} \delta^{\prime}(\xi)}{1-\chi},
$$

from which

$$
\phi(\xi, 0)=\frac{A P_{0}}{(1-\chi)\left(c^{2}-c_{R}^{2}\right)}\left(H(\xi)-\frac{1}{2}\right) .
$$

A resonant nature of the surface wave is now immediately observed from (20). It should also be noted that the constant of integration is chosen from symmetry considerations, and cannot be uniquely determined from analysis of the steady-state regime, for more details see [20].

The solution of the Dirichlet problem for an elliptic equation (17) with boundary value (20) may now be obtained through the Poisson integral formula [21], giving

$$
\phi\left(\xi, x_{3}\right)=\frac{A P_{0}}{\pi(1-\chi)\left(c^{2}-c_{R}^{2}\right)} \arctan \frac{\xi}{\lambda x_{3}} .
$$

Using (13) and (14), the resulting displacement components are obtained in the form

$$
\begin{gathered}
u_{1}\left(x_{1}, x_{3}, t\right)=\frac{A P_{0}}{\pi(1-\chi)\left(c^{2}-c_{R}^{2}\right)}\left[\arctan \frac{\xi}{\lambda_{1} x_{3}}-\chi \arctan \frac{\xi}{\lambda_{2} x_{3}}\right], \\
u_{3}\left(x_{1}, x_{3}, t\right)=\frac{A P_{0}}{2 \pi(1-\chi)\left(c^{2}-c_{R}^{2}\right)}\left[\gamma_{1} \ln \left(\xi^{2}+\lambda_{1}^{2} x_{3}^{2}\right)-\gamma_{2} \chi \ln \left(\xi^{2}+\lambda_{2}^{2} x_{3}^{2}\right)\right] .
\end{gathered}
$$

We note that the range of validity of the derived formulations is specified to near-resonant case only

$$
\left|c-c_{R}\right| \ll 1 .
$$

However, the analysis of a transient moving load problem within isotropic framework [7] revealed that the actual range of applicability of the obtained approximate solution is rather wide. For example, in the sub-critical case the developed model seemed to capture qualitative behaviour up to the values of $c=0.7 c_{R}$. 


\section{CONCLUDING REMARKS}

Analysis of the near-resonant regimes of a moving load on a transversely isotropic half-plane within steady-state assumption has been presented. The representation of the surface wave field in terms of a single harmonic function (13) and (14) has been employed along with the hyperbolic equation (9) arising from the asymptotic model oriented to surface wave field only. As a result, a simple analytical solution in terms of elementary functions has been obtained. The resonant nature of the surface wave has also been clearly illustrated. The derived asymptotic solutions are expected to provide reasonable approximation for loads travelling at speeds close to that of surface wave speed.

The presented approach could be extended to transient moving load problem similarly to [7]. Another possible directions of further development are associated with 3D formulations considered in [12], and mixed problems of elastodynamics, see [22].

\section{References}

1. Shamalta M., Metrikine A. V. Analytical study of the dynamic response of an embedded railway track to a moving load. Arch. Appl. Mech., 2003, vol. 73, pp. 131-146. DOI: 10.1007/s00419-002-0248-3.

2. Cao Y., Xia H., Li Z. A semi-analytical/FEM model for predicting ground vibrations induced by highspeed train through continuous girder bridge. $J$. Mech. Sci. Technol., 2012, vol. 26, pp. 2485-2496. DOI: 10.1007s12206-012-0630-1.

3. Cole J., Huth J. Stresses produced in a half plane by moving loads. J. Appl. Mech., 1958, vol. 25, pp. 433-436.

4. Madshus C., Kaynia A. M. High-speed railway lines on soft ground: dynamic behaviour at critical train speed. J. Sound Vib., 2000, vol. 231, no. 3, pp. 689-701. DOI: 10.1006/jsvi.1999.2647.

5. Mukherjee S. Stresses produced by a load moving over the rough boundary of a semiinfinite transversely isotropic solid. Pure Appl. Geophys., 1969, vol. 72, pp. 45-50. DOI: 10.1007/BF00875691.

6. De Hoop A. T. The moving-load problem in soil dynamics - the vertical displacement approximation. Wave Motion, 2002, vol. 36, pp. 335-346. DOI: 10.1016/S0165-2125(02)000288

7. Kaplunov J., Nolde E., Prikazchikov D. A. A revisit to the moving load problem using an asymptotic model for the Rayleigh wave. Wave Motion, 2010, vol. 47, pp. 440-451. DOI: 10.1016/j.wavemoti.2010.01.005.

8. Kaplunov J., Prikazchikov D. A. Explicit models for surface, interfacial and edge waves in elastic solids. Dynamic localization phenomena in elasticity, acoustics and electromagnetism (Eds. R. Craster, J. Kaplunov), CISM Lecture Notes, SpringerVerlag, 2013, vol. 547, pp. 73-114.

9. Kaplunov Yu. D., Kossovich L. Yu. Asymptotic model of Rayleigh waves in the far-field zone in an elastic half-plane. Doklady Physics, 2004, vol. 49, no. 4, pp. 234-236.

10. Kaplunov J., Zakharov A., Prikazchikov D. A. Explicit models for elastic and piezoelastic surface

waves. IMA J. Appl. Math., 2006, vol. 71, pp. 768782. DOI: $10.1093 /$ imamat/hx1012.

11. Chadwick P. Surface and interfacial waves of arbitrary form in isotropic elastic media. J. Elast., 1976, vol. 6, pp. 73-80. DOI: 10.1007/BF00135177.

12. Kaplunov J., Prikazchikov D. A., Erbas B., Sahin O. On a 3D moving load problem in an elastic half space. Wave Motion, 2013, vol. 50, pp. 1229-1238. DOI: 10.1016/j.wavemoti.2012.12.008.

13. Erbas B., Kaplunov J., Prikazchikov D. A., Sahin O. The near-resonant regimes of a moving load in a three-dimensional problem for a coated elastic half-space. Math. Mech. Solids, 2014. DOI: 10.1177/1081286514555451.

14. Mukhomodiarov R. R., Prikazchikov D. A. Asymptotic model for the Rayleigh wave in case of a transversely isotropic half-plane. XVIII Session of International School on the Models of Continuum Mechanics : Proc. Int. Conf., Saratov, Saratov Univ. Press, 2007, pp. 210-213 (in Russian).

15. Prikazchikov D. A. Rayleigh waves of arbitrary profile in anisotropic media. Mech. Res. Comm., 2013, vol. 50, pp. 83-86. DOI: 10.1016/j.mechrescom.2013.03.009.

16. Buchwald V. T. Rayleigh waves in transversely isotropic media. Quart. J. Mech. Appl. Math., 1961, vol. 14, pp. 293-318. DOI: 10.1093/qjmam/14.3.293.

17. Ting T. C. T. Anisotropic elasticity. Oxford, Oxford Univ. Press, 1996, 570 p.

18. Royer D., Dieulesaint E. Elastic Waves in Solids. II. Berlin, Springer, 2000, 446 p.

19. Kiselev A. P., Parker D. F. Omni-directional Rayleigh, Stoneley and Scholte waves with general time dependence. Proc. Roy. Soc. London A, 2010, vol. 466, pp. 2241-2258. DOI: 10.1098/rspa.2009.0595.

20. Kaplunov J. D. Transient dynamics of an elastic half-plane subject to a moving load. Institute for Problems in Mechanics. Preprint / USSR Academy of Sciences, 1986, no. 277, 53 p. (in Russian). 
21. Courant R., Hilbert D. Methods of Mathematical Physics. Vol. 2. New York, Wiley, 1966, 811 p.

22. Erbas B., Kaplunov J., Prikazchikov D. A. The
Rayleigh wave field in mixed problems for a halfplane. IMA J. Appl. Math., 2013, vol. 78, pp. 10781086. DOI: $10.1093 /$ imamat/ hxs010.

УДК 539.3

\section{Околорезонансные режимы в стационарной задаче о подвижной нагрузке в случае трансверсально изотропной упругой полуплоскости}

\section{Д. А. Приказчиков}

Кандидат фризико-математических наук, лектор по прикладной математике, касредра математики и компьютерных наук, Кильский университет, Великобритания, d.prikazchikov@keele.ac.uk

Рассматриваются автомодельные(стационарные) режимы в задаче о подвижной нагрузке в случае трансверсально изотропной упругой полуплоскости. Решение опирается на асимптотическую гиперболико-эллиптическую модель для поля поверхностной волны, что позволяет получить существенные упрощения в околорезонансной области. В частности, формулировка сводится к задаче Дирихле для уравнения Лапласа, имеющей явное решение выраженное в терминах элементарных фрункций. Полученные приближения могут быть использованы при скоростях нагрузки, близких к критической скорости поверхностной волны.

Ключевые слова: движущаяся нагрузка, трансверсально изотропный, около-резонансный.

\section{Библиографический список}

1. Shamalta M., Metrikine A. V. Analytical study of the dynamic response of an embedded railway track to a moving load // Arch. Appl. Mech. 2003. Vol. 73. P. 131-146. DOI: 10.1007/s00419-002-0248-3.

2. Cao Y., Xia H., Li Z. A semi-analytical/FEM model for predicting ground vibrations induced by highspeed train through continuous girder bridge // J. Mech. Sci. Technol. 2012. Vol. 26. P. 2485-2496. DOI: 10.1007s12206-012-0630-1.

3. Cole J., Huth J. Stresses produced in a half plane by moving loads // J. Appl. Mech. 1958. Vol. 25. P. 433-436.

4. Madshus C., Kaynia A. M. High-speed railway lines on soft ground : dynamic behaviour at critical train speed // J. Sound Vib. 2000. Vol. 231, № 3. P. 689 701. DOI: $10.1006 /$ jsvi.1999.2647.

5. Mukherjee $S$. Stresses produced by a load moving over the rough boundary of a semi-infinite transversely isotropic solid // Pure Appl. Geophys. 1969. Vol. 72. P. 45-50. DOI: 10.1007/BF00875691.

6. De Hoop A. T. The moving-load problem in soil dynamics - the vertical displacement approximation // Wave Motion. 2002. Vol. 36. P. 335-346. DOI: 10.1016/S0165-2125(02)00028-8

7. Kaplunov J., Nolde E., Prikazchikov D. A. A revisit to the moving load problem using an asymptotic model for the Rayleigh wave // Wave Motion. 2010. Vol. 47. P. 440-451. DOI: 10.1016/j.wavemoti.2010.01.005.

8. Kaplunov J., Prikazchikov D. A. Explicit models for surface, interfacial and edge waves in elastic solids // Dynamic localization phenomena in elasticity, acoustics and electromagnetism / eds.
R. Craster, J. Kaplunov. CISM Lecture Notes. Springer-Verlag, 2013. Vol. 547. P. 73-114.

9. Каплунов Ю. Д., Коссович Л. Ю. Асимптотическая модель для вычисления дальнего поля волны Рэлея в случае упругой полуплоскости // Докл. AH. 2004. T. 395, № 4. C. 484-484.

10. Kaplunov J., Zakharov A., Prikazchikov D. A. Explicit models for elastic and piezoelastic surface waves // IMA J. Appl. Math. 2006. Vol. 71. P. 768782. DOI: 10.1093/imamat/hx1012.

11. Chadwick $P$. Surface and interfacial waves of arbitrary form in isotropic elastic media // J. Elast. 1976. Vol. 6. P. 73-80. DOI: 10.1007/BF00135177.

12. Kaplunov J., Prikazchikov D. A., Erbas B., Sahin O. On a 3D moving load problem in an elastic half space // Wave Motion. 2013. Vol. 50. P. 12291238. DOI: 10.1016/j.wavemoti.2012.12.008.

13. Erbas B., Kaplunov J.. Prikazchikov D. A., Sahin O. The near-resonant regimes of a moving load in a three-dimensional problem for a coated elastic half-space // Math. Mech. Solids. 2014. DOI: 10.1177/1081286514555451.

14. Мухомодьяров Р. Р., Приказчиков Д. А. Асимптотическая модель волны Релея в случае трансверсально-изотропной упругой полуплоскости // XVIII сессия международной школы по моделям механики сплошной среды : материалы междунар. науч. конф. Саратов : Изд-во Сарат. ун-та, 2007. C. 210-213.

15. Prikazchikov D. A. Rayleigh waves of arbitrary profile in anisotropic media // Mech. Res. Comm. 2013. Vol. 50. P. 83-86. DOI: 10.1016/j.mech rescom.2013.03.009. 
16. Buchwald V. T. Rayleigh waves in transversely isotropic media // Quart. J. Mech. Appl. Math. 1961. Vol. 14. P. 293-318. DOI: 10.1093/qjmam/14.3.293.

17. Ting T. C. T. Anisotropic elasticity. Oxford: Oxford Univ. Press, 1996. 570 p.

18. Royer D., Dieulesaint E. Elastic Waves in Solids II. Berlin : Springer, 2000. $446 \mathrm{p}$

19. Kiselev A. P., Parker D. F. Omni-directional Rayleigh, Stoneley and Scholte waves with general time dependence // Proc. Roy. Soc. London A. 2010. Vol. 466. P. 2241-2258. DOI: 10.1098/rspa.2009. 0595 .
20. Каплунов Ю. Д. Нестационарная динамика упругой полуплоскости при действии подвижной нагрузки. Препринт / ИПМ АН СССР. 1986. № 277. 53 c.

21. Courant R., Hilbert D. Methods of Mathematical Physics. Vol. 2. N.Y. : Wiley 1966. 811 p.

22. Erbas B., Kaplunov J.. Prikazchikov D. A. The Rayleigh wave field in mixed problems for a halfplane // IMA J. Appl. Math. 2013. Vol. 78. P. 10781086. DOI: 10.1093/imamat/ hxs010. 